\title{
Development of the Tax System in the Slovak Republic after 1993 and Prospects for Tax Harmonization as A Member of the European Union
}

\author{
Kristína Vrtíková \\ Faculty of Business Management, Economic University in Bratislava, \\ Dolnozemskácesta 1, Bratislava, 85235 Slovakia
}

\begin{abstract}
The emergence of taxes and the tax system has historically been associated with the development of the state. The tax system of Slovak Republic passed in 1993 after several major reforms. Taxes are economic and financial instruments that the government affects not only the functioning of economic entities but also households and individuals. Taxes are categorized in several ways, most often regarding related taxes for the taxpayer, on direct and indirect taxes. Tax systems are made up of elements which include: tax quota, tax mix, tax structure and others. One of the most important macroeconomic indicators of the tax is tax quota. This indicator represents the share of taxes in GDP, and it is used in international comparison. An important and often discussed topic is tax harmonization in the European Union, which aims to bring member states together and create a strong, economically, politically and culturally unified group of countries. The aim of harmonization is to protect the common market, the removal of fiscal frontiers in the European Union, focusing mainly on direct and indirect taxes.
\end{abstract}

Keywords: Taxes, Taxation, Reforms, Harmonization, Competition

\section{INTRODUCTION}

One of the oldest financial instruments are taxes that serve multiple purposes. Since the beginning of the formation of the money economy, taxes were part of the life of individuals and society at large. One of the most important functions of taxes for the state and the leadership of the state has been the primary funding needs of the state as well as the implementation and achievement of individual objectives of the state. Functions and nature of the tax have varied over time. From initial random, tax has become a regular and financial income, which gave the basis for the formation of tax policy of the state. Taxes have become an important macroeconomic tool.

\subsection{Tax scheme}

Tax scheme is a narrower concept than the tax system because tax scheme together with the institutions, legislation, and tax theory constitute the tax system. In the view of Kassay (2008), tax system is of great importance for the social sector of the economy. Just as the tax system affects a number of factors, taxation affects certain factors, such as inflation rates, economic growth, linking domestic and foreign trade and sectoral structure.

The first individual pension tax was used in the UK in the late $18^{\text {th }}$ century, and the first comprehensive system of social security appeared in Bismarck, Germany. For the first time, at the end of the nineteenth century, this became known as tax systems. In this period, Europeans started developing their countries by the first tax reforms. 
Tax reforms were conducted in three waves and had a significant impact on all countries. The first wave was associated with the department of social security contributions from pension insurance. This reform ran from 1945 to 1965 . This period was influenced by Keynes policies and the intensification of the role of the state in the economy resulting in a high redistribution of taxes. The second wave is associated mainly with France in 1967, when they first introduced the value added tax and excise duty. However, this step of negotiation, the Rome Agreement, was in Belgium, Netherlands, Luxembourg, France, Italy, and Germany already in 1956. By the end of 1991, VAT was introduced in eighteen other countries. The third wave was intended to restore a sluggish economy through the implementation of supply-side policies.

Behind this wave of reforms, President Regan (USA) set three main objectives:

- to clarify the law and to introduce transparency and fairness of taxation;

- to increase the economic incentive to operators, since it was weakened due to high taxation;

- to introduce fiscal neutrality by removing tax credits and adjusting the tax mix focusing on indirect taxes.

According to Schultzová (2011), due to the fact that individual countries have different tax systems through their tax policies, which govern the behavior of the operators, it is not possible to introduce a unified tax system for all states. The differences are apparent in the structure of the tax system of taxation on income and capital, adjustment of the tax base, shifting of the tax burden between direct and indirect taxes and redistribution of tax revenues between the government and levels of government. An effective tax system should observe the principle of neutrality of taxation, according to which economic agents make their decisions, regardless of the tax consequences (Kubicova, 2009).

Another perspective on the optimal tax system, according to Musgrave (2011), is that the tax system should offer sufficient revenue from taxation. There should be a unified distribution of the tax burden, proper tax transfer tackling, ensured tax collection system so that entity should be least interfered for their administrative costs to be kept to a minimum in this matter. Additional requirements for the optimal tax system are that the use of stabilization and fiscal policy should be clear and understandable, and should allow the consistent and inexpensive report.

One of the ways to influence the tax system is the "branch structure". In some enterprises, it can be expected by the number of employees. The more companies in the country are employing people, the less will be self-employed. Under this assumption, it can be concluded that taxation of employees is relatively easy because the tax is precipitated directly from wages and the tax base is not affected by an overload of deductible items as for individual entrepreneurs. Using this information, the government can count on relatively easily predictable revenue from the tax on personal income. Conversely, in countries where there are a greater number of individual entrepreneurs consumption taxes mostly contribute to tax revenues.

\subsection{Measuring the tax burden}

One of the most important macroeconomic indicators is the tax burden. This indicator represents the share of taxes in GDP, and it is used in international cooperation. We distinguish the following types of quotas:

- simple tax quota;

- complex tax quota.

A simple tax quota represents tax revenues to the state budget and it is treated as taxes. Complex tax quota is more meaningful because along with simple tax quota, it includes social security contributions, health insurance and contribution to the state employment support.

In Slovakia, there are three types of tax allowances; Tax quota I, Tax quota II and Tax quota III. 


\section{Kristína Vrtíková}

Development of the Tax System in the Slovak Republic after 1993 and Prospects for Tax Harmonization as A Member of the European Union

Tax quota $I$ is the set of all direct and indirect taxes. Tax quota $I I$ consists of income accruing to the fund of social health protection. The tax quota III includes other charges such as franchising, licensing certification fees and road signs.

Based on the features of each country, tax quotes say nothing about the tax burden of individuals, but ultimately the wearer of the citizen.

The tax mix is the structural arrangement of the tax allowances on individual particularities and contains the following six kinds of taxes:

1. tax on income profits and capital gains;

2. social security contributions;

3. the tax on wages and labor;

4. property taxes;

5. commodity taxes and taxes on service;

6. Other taxes.

Countries where the value of the tax mix will not change rapidly are characterized by strong tax compliance, social security contributions, and a high tax burden. By contrast, in economies with unstable tax compliance and the unwillingness of the population to pay taxes, as well as low-income population, the government often relies on the contribution of indirect taxes and tends to increase the tax burden.

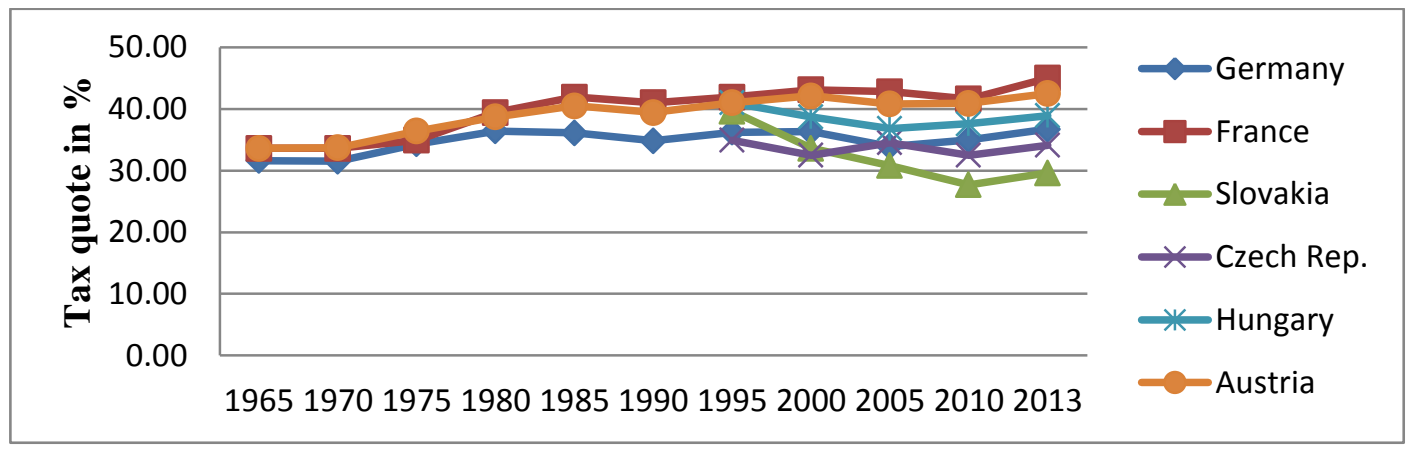

Graph 1: Tax quotes in select countries

Source: OECD Revenue Statistics 1965-201. Revenue Statistics tax changes between 1965-201.

[Online]. [cit. 2015.04.13]. Available at: http://stats.oecd.org/index.aspx?DataSetCode=REV, own processing

Figure 1 shows the states with the highest tax burden as a percentage of GDP. Among the countries with the highest burden, there is Denmark, Norway, Sweden, Finland, France, Belgium, Italy and Austria with a load of more than $40 \%$. The tax burden in the range of 36 $40 \%$ of GDP are countries like Germany, Holland, Hungary, Slovenia and England. Between $30 \%-35 \%$ of GDP are countries like Iceland, Poland, Czech Republic, Spain, and Portugal. Below the $30 \%$ of GDP is Slovakia, Ireland, Romania, Lithuania, and Latvia. 


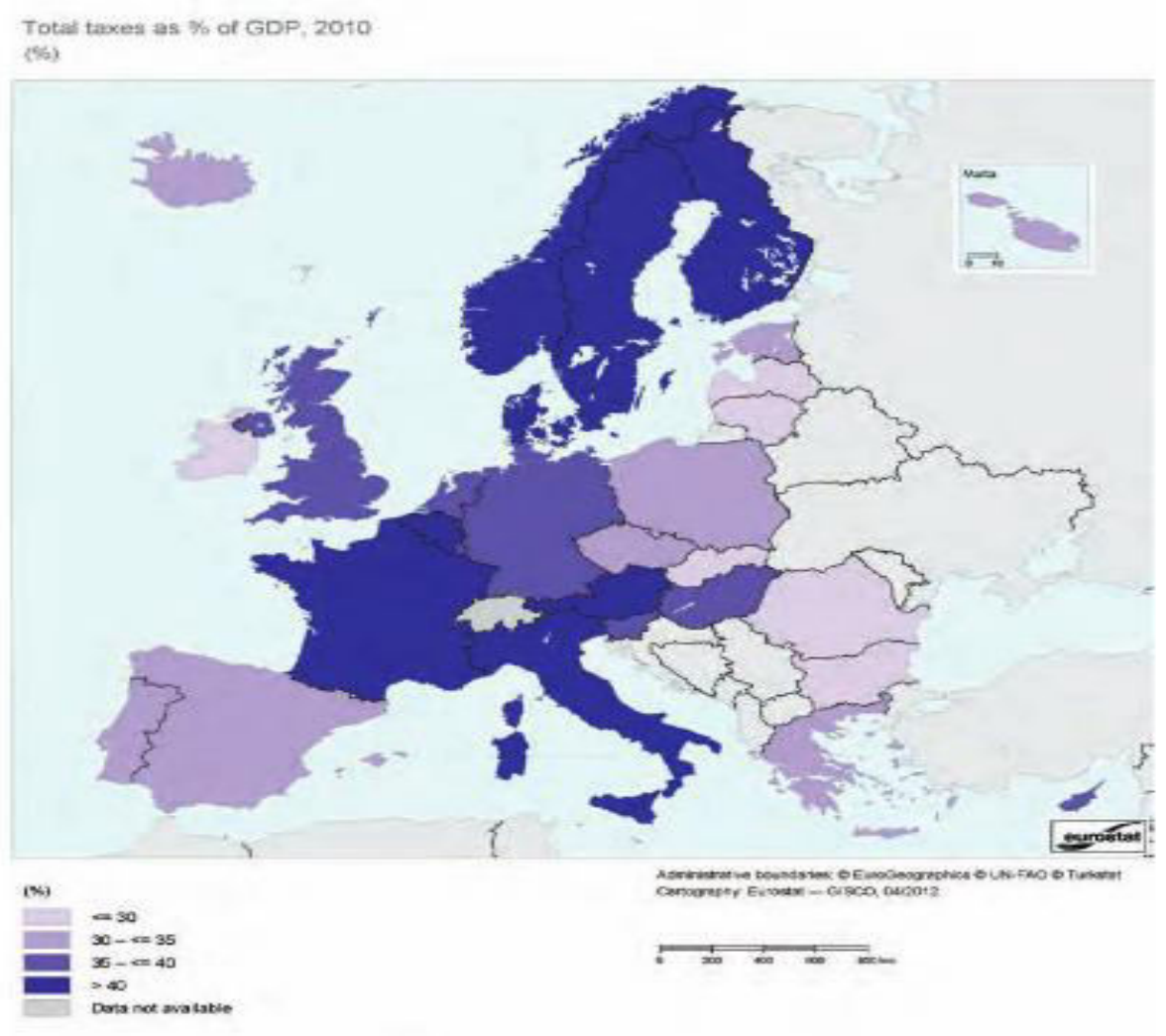

Figure 1: Taxation trends in the European Union

Source: EUROSTAT. 2012. Taxation trends in the European Union. [online]. [cit. 2015.10.05]. Avaliableat:http://ec.europa.eu/taxation_customs/resources/documents/taxation/gen info/economic_ analysis/tax structures/2009/2009 main results en.pdf

Since 2009, the standard rate of VAT had an increasing trend in most Member States of the European Union. The average amount of the VAT rate in the EU increased by two percentage points from $19.5 \%$ in 2008 to $21.5 \%$ in 2014 (see Graph 2). In this period, 20 Member States recorded growth rates of default. In 2014, the basic rate of VAT in France, Italy, and Cyprus has increased, but the highest rate of VAT happeded in Hungary (27\%), followed by Croatia, Denmark and Sweden (the VAT of $25 \%$ in all countries). VAT rates are the lowest in Luxembourg (15\%) and Malta (18\%).

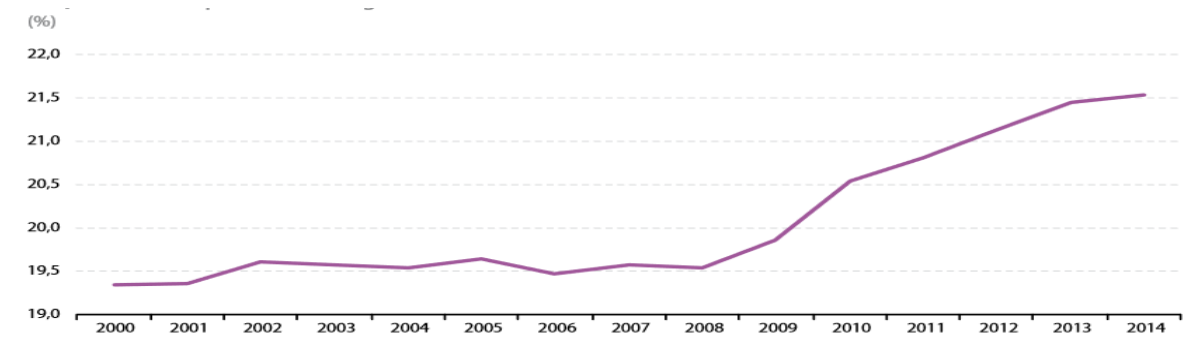

\section{Graph 2: Development of average standard VAT rate, EU-28, 2000-14}

Source: EUROSTAT. 2012. Taxation trends in the European Union. [online]. [cit. 2015.10.05]. Available at: http://ec.europa.eu/taxation customs/resources/documents/taxation/gen info/economic analysis/tax structures/2 $\underline{009 / 2009 \text { main results en.pdf }}$ 


\section{Tax system of the Slovak Republic}

The Slovak Republic, as a member of the European Union, uses to fulfil the state budget with several types of taxes. The current tax system of the Slovak Republic flexibly responds to changes and requirements arising from EU membership. Slovakia's access to the European Union put an obligation to harmonize the tax system in Slovakia with EU law.

Along with the development of the Slovak Republic in 1993, it started to form the first tax system. Changes, associated with this step are particularly expressed in the Income Tax Act. Tax on income from literary and artistic activities and population income tax was replaced by a tax on the income of individuals. Corporate income tax is introduced to create the conditions by replacing levies taxation on profits, income, and agricultural taxes. In the beginning, the amount of the rates for legal entities was $40 \%$ and it gradually came to a level of $23 \%$ in 2013 to current $22 \%$ from 2014 .

Tax calculation is also introducing a unified and progressive sliding calculation of the tax base. Slovak tax system is formed by three kinds of tax legislation consisting of direct taxes, indirect taxes, and local taxes.

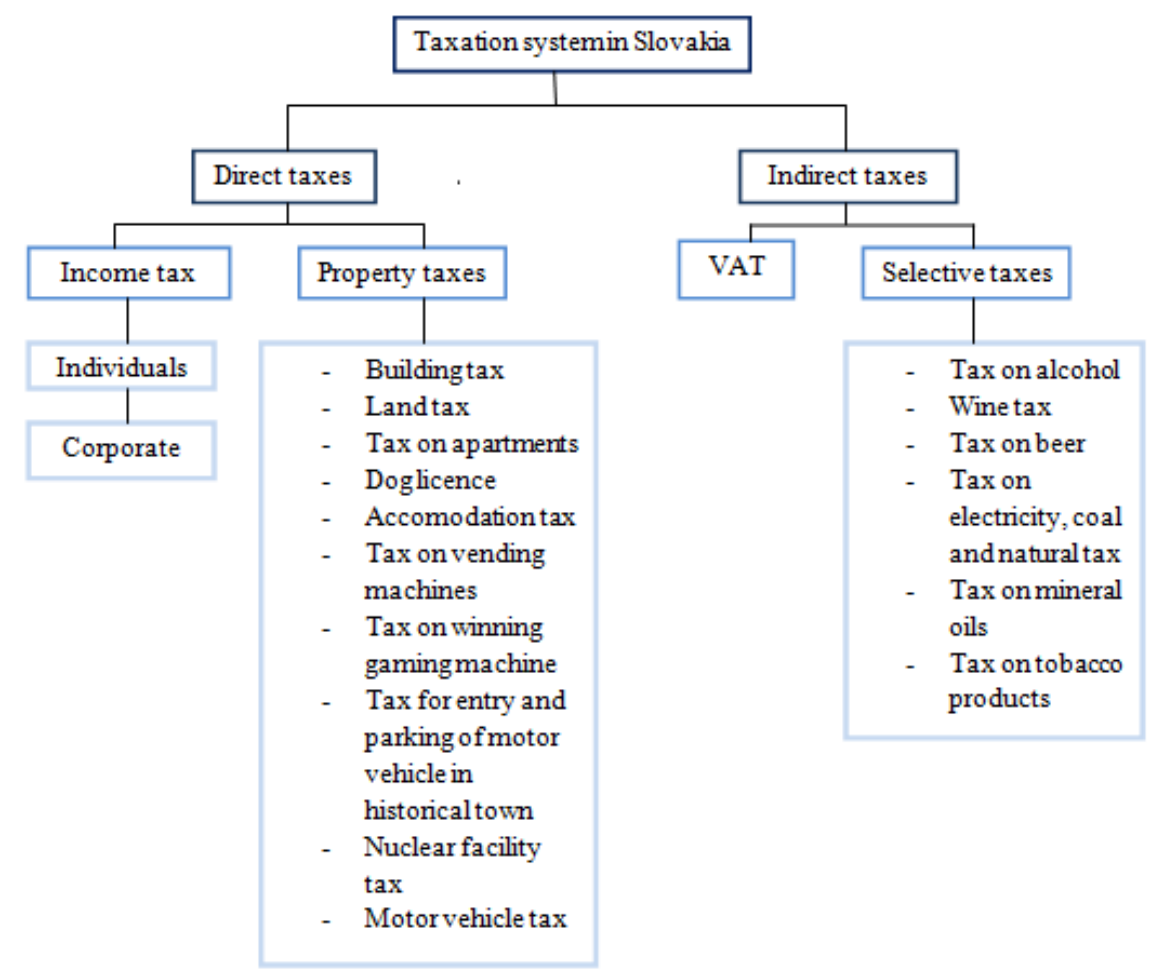

Figure 2: Taxation system in Slovakia

Source: MEDVEĎ, J., NEMEC, J. et al. 2011. Verejné financie. Bratislava: Sprint dva, 2011. 640 s. ISBN 978-80-89393-46-6.

\subsection{The development of tax reform in Slovakia after 1993}

Tax reforms in the Slovak Republic developed in several stages. The year 1993 was significant for several reasons. Because of the division of Czechoslovakia, the beginning of the tax systems in Czech Republic and Slovakia were identical, as well as the newly introduced accounting system. In 1993, there started the introduction of changes in the social and health insurance, as well as, unemployment insurance. The first tax reform was part of the changes in economic, financial and social sectors. Although, there was an identical character in the tax systems in these two countries, they went to different direction after the split and differences in the system increase. 
The tax reforms in 1993 were determined to create a market-based tax system, ensuring the elasticity of revenue and expenditure of the state budget to Gross Domestic Product. Other objectives included as zooming tax quota to that applied in countries with a market economy, the creation of a level playing field for all businesses, promote socially desirable economic activities, use the tax system to address environmental problems and approach the newly created tax system, the system of the European Communities (European Union).

The result of the tax reform in 1995 was to reduce the weight of direct taxes. This step was achieved by shifting the tax burden from direct to indirect taxes, as they regard tax collection to become easier. The year 2004 was especially important for further stages in the development of the tax system in the Slovak Republic. There were complicated, confusing and ambiguous tax laws, the need to simplify and clarify the total until the established tax system in Slovakia. The Slovak Government has concluded that it is necessary to establish a simpler tax system with fewer exemptions, which result in improved controllability, transparency and simplicity of the tax laws of all tax entities. The tax reform consistently applied the principles of taxation as fairness, neutrality, simplicity and efficiency in the tax system of the Slovak Republic. The reform simplified tax legislation and a fiscally neutral tax reform to shift taxation from direct tax to indirect tax, shifted the taxation of pension tax on tax on consumption and property taxes and introduced a flat tax.

R. E. Hall and A. Rabushka government wanted a positive impact on the business environment, increase employment and increase the inflow of foreign investments and there introduced the flat tax of $19 \%$ on personal income.

A comprehensive package of structural reforms has been linked with a clear strategy for improving the business environment and increasing the degree of economic freedom. Slovakia has made since the mid-1990s and to this day the fastest drop rate of redistribution of tax and contribution rates and the burden of all the countries of the European Union. The share of public expenditure in GDP decreased in the years $1996-2006$ by $14.8 \%$ ( $52.1 \%$ to $37.3 \%$ ) and the tax quota II (a share of the revenue from taxes and levies to GDP) of $10.9 \%(40.4 \%$ at $29.5 \%)$.

In 2011, tax allowances were introduced as the part of the income tax. This tax, however, was abolished in 2012 by the order of the Constitutional Court no. 188/2012 Coll. The latest reform, which takes account of global trends and experiences from abroad, was reform in 2012. This reform aims to create a single institution that will cover the tax and customs administration, and consolidate and collection of taxes, customs duties and insurance contributions.

Another aim is to reduce bureaucracy, streamline and simplify processes related to tax and contributions, modernization and optimization of the tax system. These steps should cover all subjects covered by the tax liability. It can be said that the current tax system received its similar reforms in 2004. Since 2014, however, there were some changes in personal income when the law came into nontaxable portion, representing the amount of contributions paid by the employee to supplementary pension schemes (III. pillar).

Changes in the tax system are mainly reflected in:

- the introduction of a uniform amount of income tax rate amounting to $19 \%$ (for individuals as well as corporations), and replacing the previous tax on corporate income tax of $25 \%$ and personal income tax rate from $10 \%$ to $38 \%$,

- the introduction of higher tax allowance for taxpayers and tax bonus for a child,

- repeal a number of exemptions, deductions and special relief in taxation of income tax,

- unification of VAT rates at $19 \%$ (replacing the basic rate of $20 \%$ and the reduced rate of $14 \%$ ),

- the increase in excise duties on rates required by the European Union,

- abolition of tax on dividends,

- abolition of gift tax and inheritance,

- abolition of assignment or transfer of property (since 2005). 
Kristína Vrtíková

Development of the Tax System in the Slovak Republic after 1993 and Prospects for Tax Harmonization as A Member of the European Union

Table 1: The share of tax revenue to GDP in percentage

\begin{tabular}{|l|l|l|l|l|l|l|l|l|l|l|l|l|}
\hline $\begin{array}{l}\text { Tax revenue } \\
\text { on } \\
\text { annual basis } \\
\text { (cash,\% of } \\
\text { GDP) }\end{array}$ & $\mathbf{2 0 0 3}$ & $\mathbf{2 0 0 4}$ & $\mathbf{2 0 0 5}$ & $\mathbf{2 0 0 6}$ & $\mathbf{2 0 0 7}$ & $\mathbf{2 0 0 8}$ & $\mathbf{2 0 0 9}$ & $\mathbf{2 0 1 0}$ & $\mathbf{2 0 1 1}$ & $\mathbf{2 0 1 2}$ & $\mathbf{2 0 1 3}$ & $\mathbf{2 0 1 4}$ \\
\hline Direct taxes & $\mathbf{6 , 3}$ & $\mathbf{5 , 1}$ & $\mathbf{5 , 6}$ & $\mathbf{5 , 5}$ & $\mathbf{5 , 5}$ & $\mathbf{6 , 1}$ & $\mathbf{6 , 1}$ & $\mathbf{4 , 3}$ & $\mathbf{4 , 9}$ & $\mathbf{5 , 2}$ & $\mathbf{5 , 5}$ & $\mathbf{5 , 4}$ \\
\hline $\begin{array}{l}\text { Tax on the } \\
\text { income of } \\
\text { natural } \\
\text { persons }\end{array}$ & 3,2 & 2,4 & 2,6 & 2,4 & 2,4 & 2,7 & 2,6 & 2,2 & 2,4 & 2,5 & 2,5 & 2,6 \\
\hline $\begin{array}{l}\text { Tax on } \\
\text { income of } \\
\text { legal persons }\end{array}$ & 2,4 & 2,3 & 2,8 & 2,8 & 2,8 & 3,1 & 3,3 & 1,9 & 2,3 & 2,4 & 7 & 2,5 \\
\hline $\begin{array}{l}\text { Refundable } \\
\text { withholding }\end{array}$ & 0,7 & 0,4 & 0,3 & 0,3 & 0,3 & 0,3 & 0,2 & 0,2 & 0,2 & 0,2 & 0,2 & 0,2 \\
\hline $\begin{array}{l}\text { Indirect } \\
\text { taxes }\end{array}$ & $\mathbf{1 1 , 2}$ & $\mathbf{1 1 , 5}$ & $\mathbf{1 2 , 4}$ & $\mathbf{1 1 , 6}$ & $\mathbf{1 1 , 2}$ & $\mathbf{1 0 , 4}$ & $\mathbf{9 , 9}$ & $\mathbf{1 0 , 5}$ & $\mathbf{1 0 , 6}$ & $\mathbf{1 0 , 0}$ & $\mathbf{1 0 , 5}$ & $\mathbf{1 0 , 6}$ \\
\hline VAT & 6,7 & 7,1 & 8,0 & 7,6 & 7,2 & 6,8 & 6,0 & 6,6 & 6,8 & 6,0 & 6,4 & 6,5 \\
\hline Excise duties & 3,0 & 3,1 & 3,3 & 3,1 & 3,1 & 2,8 & 2,9 & 2,9 & 2,9 & 2,7 & 2,7 & 2,7 \\
\hline $\begin{array}{l}\text { Property } \\
\text { taxes }\end{array}$ & 0,5 & 0,5 & 0,5 & 0,4 & 0,4 & 0,3 & 0,4 & 0,4 & 0,4 & 0,4 & 0,4 & 0,4 \\
\hline Local taxes & 0,2 & 0,2 & 0,2 & 0,2 & 0,2 & 0,1 & 0,2 & 0,2 & 0,2 & 0,2 & 0,2 & 0,2 \\
\hline Other taxes & 0,0 & 0,0 & 0,0 & 0,0 & 0,0 & 0,0 & 0,0 & 0,0 & 0,0 & 0,3 & 0,4 & 0,4 \\
\hline $\begin{array}{l}\text { Total tax } \\
\text { revenues }\end{array}$ & $\mathbf{1 7 , 5}$ & $\mathbf{1 6 , 6}$ & $\mathbf{1 8 , 0}$ & $\mathbf{1 7 , 1}$ & $\mathbf{1 6 , 7}$ & $\mathbf{1 6 , 5}$ & $\mathbf{1 6 , 0}$ & $\mathbf{1 4 , 7}$ & $\mathbf{1 5 , 5}$ & $\mathbf{1 5 , 1}$ & $\mathbf{1 6 , 0}$ & $\mathbf{1 6 , 0}$ \\
\hline
\end{tabular}

Source: Ministry of Finance, Slovak Republic. 2015. Daňové indikátory. [online]. [cit. 2015.12.27]. Avaliable at: http://www.finance.gov.sk/Default.aspx?CatID $=7432$

Tax reform built on the flat tax has brought about positive results. The share of tax revenue to GDP was not changed, and Slovakia has managed to achieve fiscal neutrality. The only visible change was the decrease in the share of income tax of physical persons.

According to Lenártová (2012), function of taxation "is the most important economic decision of the state because its design and quality affects the vast majority of economic processes throughout the economy both nationally and internationally." The amount of taxation has a major influence on the decisions of businesses in carrying out its activities, affecting the living standards of the population, the rate of investment and the amount of final consumption. Currently, when globalization plays an important role for business, it is much easier to start a business in the country which offers better conditions. It is necessary to create conditions that support and motivate entrepreneurs to perform their activities.

The main principles of the tax reform in the Slovak Republic include:

- application of taxation principles as fairness, simplicity, neutrality, efficiency,

- simplify the tax system,

- fiscally neutral tax reform,

- the emphasis burden from direct to indirect taxation,

- the introduction of the flat tax,

- abolition of progressive taxation,

- the abolition of double taxation.

Another view on tax reform is offered by S. James which is called "Force field approach" which means businesses can formulate their observations and requirements for the effective tax system. The figure 
shows the process of changing the current tax system through pressure exerted by entrepreneurs and others. In the event of lack of funds in the state budget, the government is trying to take such measures to change this situation. Fears and reluctance to implement change occur on the part of taxpayers due to a higher tax burden. These differences result in a compromise when designing and implementing tax changes.

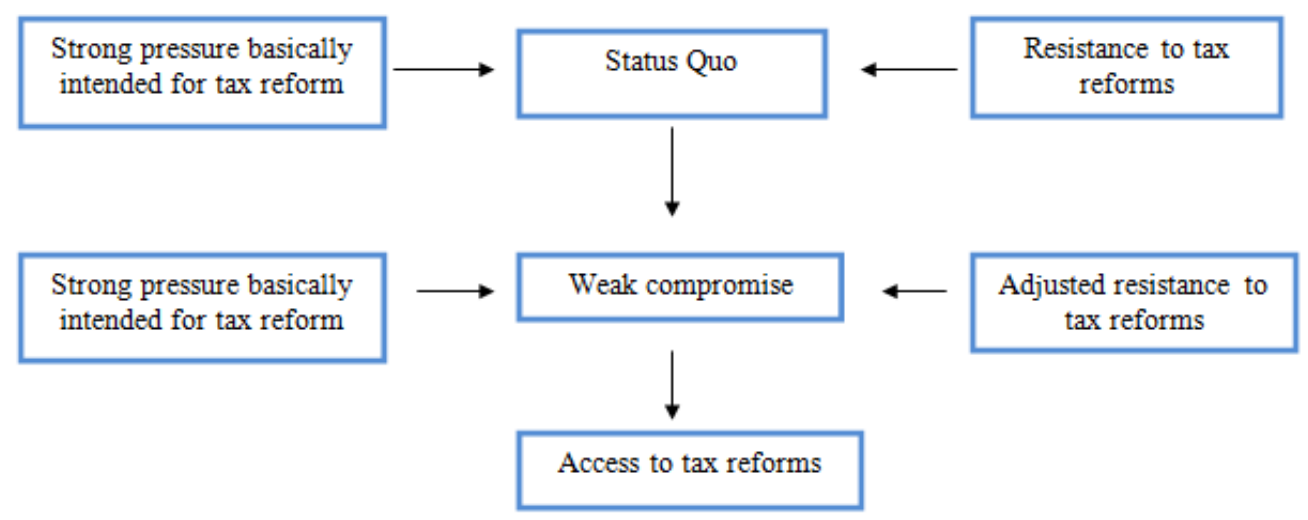

Figure 3: Force field approach

Source: James, S. 2002. The Future International Tax Environment. In The International Taxation System. Kluwer Academic Publishers.: Boston/Dordrecht/London. 2002. s. 108. ISBN 1 -4020-7157-4.

\section{Prospects of tax harmonization in the European Union}

Tax harmonization is the highest degree of unification of tax systems of all the Member States of the European Union by unified rules. In the process of harmonization, there identified three basic phases, namely: harmonization of the tax base, harmonization of tax rates and harmonization of tax administration. The European Union aims to create a grouping of states with strong political, cultural and economic grounds, which should assist in economic decision-making.

Tax harmonization is a process and the result. We can understand it as a process of harmonization to achieve results, but it presents itself as a result of harmonization of tax legislation. In the case of understanding of harmonization as a means of achieving a single market, we can distinguish positive and negative harmonization.

Positive harmonization is a process of gradual harmonization of national economies and tax systems of the States of the European Community based on the implementation of the guidelines and legislative instruments used by the European Commission to promote harmonization. The aim of harmonization is to introduce a positive to the same rules for all Member States.

Negative harmonization measures by the European Court of Justice on the basis of accepted guidelines and regulations. Negative results of harmonization are different rules for the Member States. A necessary step for the introduction of tax harmonization is unanimous agreement by all Member States, taking into account the specific intention of the State, national policies and interests representing one of the biggest obstacles.

According to Ficbauer (2011), there exist constraints on tax harmonization in the European Union. Such elements include:

- $\quad$ personal income taxes, which remain the responsibility of individual states,

- corporate taxes remain the responsibility of individual states, 
- $\quad$ provided that their policy does not create harmful competition, but only the transport and movement of capital, indirect taxes remaining in the spotlight harmonization process as it affects the overall functioning of the markets,

- social and pension systems designed to limit discrimination and restrictions on freedom of investment and business in the European Union.

Tax harmonization does not necessarily mean the same definition of the tax base for all states. For political reasons, it only takes to bring them closer. The harmonization process in the Member States is not confined to its taxes, but also focuses on coordination of tax systems and the efficiency of tax administration. Harmonization affects different legal instruments, including the primary law of the European Union and secondary EU law.

The primary law of the European Union prohibited from applying a higher tax on imported products than to domestic, allow for a higher deduction for exported goods than what has been paid to them, provide relief from direct taxes to domestic exporters and stores prepare the harmonization of VAT.

The secondary law of the European Union identifies the main instruments of tax harmonization by regulations and directives of the European Community. The aim is to ensure the implementation of harmonization, method, and implementation is left to the individual countries.

\subsection{Impact of tax harmonization and tax competition}

The European Union during its existence has made considerable achievements in many areas of cooperation between the Member States and the idea of harmonizing the various tax systems is also designed to help the optimal functioning of a single internal market and better cooperation between the Member States.

There are strong pressures of tax competition advocates, who argue that tax harmonization must have certain limits. Otherwise, they will mean exceeding the inefficiency of the whole system of harmonization. Excessive intervention by the state is unrewarding and highlights the benefits of free competition of tax systems to enhance the economic incentives for individual taxes and saving funds for public budgets.

According to some authors, the positive competitive tax systems can include:

- economic stimulus competition,

- $\quad$ savings in public budgets,

- the creation of new experiences.

The negative aspects of tax competition are shifting the tax burden from capital to labour, inappropriate structure of government spending and inefficient delivery of public services. Another downside is that companies pay tax in a jurisdiction with low tax burden and use public services in jurisdictions with the high tax burden. Competition does not allow efficient allocation of resources, and may also lead to a distortion of world prices for large and strong countries.

In recent years, several Member States have taken reforms in the process of creating a common market. As a consequence of tax competition, many companies seek to relocate their businesses to countries with lower tax rates.

\section{Conclusion}

The tax system of the Slovak Republic passed a number of reforms since its inception. In the beginning, the amount of the rates for legal entities was $40 \%$ and it gradually came to a level of $23 \%$ in 2013 and to current $22 \%$ in 2014 . Tax calculation is united and introducing a progressive sliding calculation of the tax base. Slovak tax system is formed by three kinds of tax legislation, including direct, indirect and local taxes. The latest reform, which takes global trends and experiences from abroad into account, was 
reform in 2012. This reform has created a single institution that administers tax and custom and collection of taxes, customs duties and insurance contributions.

The tax burden of EU countries, as well as height and number of tax rates in the case of direct taxes show the very significant differences in the Member States. Specifics and differences in the development of each country are also reflected in large and small differences in their tax systems. Significant progress towards harmonization made by the many Member States in areas like the reciprocal exchange of tax information, avoiding double taxation, or so-called combat tax. The controversy on the harmonization of direct taxes is carried out in the European Communities for a long time to create a single market. The main objective is to harmonize the tax systems of the Member States, but this step slowed down the efforts of the Union to maintain the fiscal policy instruments in their hands.

\section{References}

- $\quad$ Eurostat. 2012. Taxation trends in the european union. [online]. [cit. 2015.10.05]. Available at: http://ec.europa.eu/taxation_customs/resources/documents/taxation/gen_info/economic_analy sis/tax_structures/2009/2009_main_results_en.pdf

- Ficbauer, j. 2011. Mezinárodní účetní standardy a daňové systémy. Ostrava: Key publishing, 2011. 168 s. ISBN 978-80-7418-104-7

- Harumová, a. - Kubátková, k. 2006. Dane podnikatel'ských subjektov. Bratislava: Poradca Podnikatel'a, 2006. 296 s. ISBN 80-8831-55-x

- James, s - Hasseldine, j. 2002. The future international tax environment. In: the international taxation system. Boston/dordrecht/ London: Kluwer Academic publishers, 2002. S.105 - 122. ISBN 1-4020-7157-4

- Kassay, š. 2008. Podnik a podnikanie. Bratislava: veda. 2008, 616 s. ISBN 978- 80-224-1032-8

- Korečko, j. 2010. Harmonizácia daní a daňové zat́aženie v krajinách eú. In: national and regional economics viii. [online]. [cit. 2015.10.07]. Available at: http://www3.ekf.tuke.sk/konfera2010/zbornik/files/prispevky/koreckojaroslav.pdf

- Kubátková, k. 2010. Daňová teória a politika. Praha: wolters kluwer, 2010. 276 s. ISBN 97880-7357-574-8

- Kubicová, i. 2009. Medzinárodné zdaňovanie. Bratislava: ekonóm, 2009. 274 s. ISBN 978-80225-2664-7

- Lenártová, g. 2012. In: verejná správa a regionálny rozvoj. Hodnotenie vývoja daňového systému slovenskej republiky v kontexte zmien od 1. Januára 201. [online]. [cit. 2015.04.14]. Dostupné na internete: http://www.vsemvs.sk/portals/0/files/vedavyskum/vedeckycasopisvsemvs_2012_12.pdf

- Martišková, a. 2014. Daňové zat́aženie vo vybraných krajinách. In: sociálno- ekonomický obzor. Bratislava: nhf ekonomická univerzita v bratislave. [online]. [cit.2015.04.15]. Available at: http://nhf.euba.sk/docs/seo/3_vydanie_sep_2014_4.pdf

- Medved', j., nemec, j. Et al. 2011. Verejné financie. Bratislava: : sprint dva, 2011. 640 s. ISBN 978-80-89393-46-6.

- Ministerstvo financií slovenskej republiky. 2015. Daňové indikátory. [online]. [cit. 2015.12.27]. Available at: http://www.finance.gov.sk/default.aspx?catid=7432

- Mussgrave, a. In: schultzová a kol. Daňovníctvo. Daňová teória a politika. Bratislava: iura edition, 2011. S. 14. ISBN 978-80-8078-407-2

- Rovná daň na slovensku. [online]. [cit.2015.12.27]. Available at: http://www.upms.sk/media/rovn da na slovensku funguje to 1.pdf

- Schultzová, a. Et al. 2011. Daňovníctvo. Daňová teória a politika. Bratislava: iura edition, 2011. 260 s. ISBN 978-80-8078-407-2

- Sivák, r. 2007. Verejné financie. Bratislava: iura edition, 2007. 311 s. ISBN 978-80-8078-094-4

- Zubal'ová, a. Et al. 2012. Daňové teórie a ich využitie v praxi. Bratislava: IURA edition, 2012. 199 s. ISBN 978-80-8078-487-4 